\title{
The goals of manufacturing strategy, P.O.M. techniques and perceptions A pilot study
}

\author{
D.R. Snaddon \\ Department of Business Economics, University of the Witwatersrand, P.O. Wits 2050, Republic of South Africa
}

Received March 1992, accepted June 1992

\begin{abstract}
Managers formulate, implement and monitor strategies to pursue their goals. Implementation is important and involves, amonst others, Production and Operations Management (P.O.M.) techniques. The purpose of this article is to study, by means of a limited sample, perceptual associations between goals of manufacturing strategy and P.O.M. techniques. An attempt is made to answer two questions in this article. The first question is which specified goals are independent of each other? The second question is which P.O.M. techniques are recommended for these independent goals? Bias and the definition of P.O.M. techniques create difficulties but pilot research indicates that some specified goals are perceived as independent. More investigation is required to verify this. Some techniques are identified with specific goals and this work should be expanded.
\end{abstract}

\begin{abstract}
Ten einde hul doelwitte te behaal, formuleer, implementeer en kontroleer bestuurders strategieè. Implementering is belangrik en bchels, onder andere, produksie- en operasionele bestuurstegnieke. In hierdie artikel word persepsies ten opsigte van die verband tussen die doelwitte van vervaardigingstrategieè en produksie- en operasionele bestuurstegnieke deur middel van 'n beperkte steckproef ontleed. In die artikel word gepoog om twee vrae te beantwoord. Die eerste vraag is watter spesifieke doclwitte onafhanklik van mekaar is? Die tweede vraag is watter produksie- en operasionele bestuurstegnieke vir die bereiking van hierdie onafhanklike doelwitte aanbeveel word? Sydigheid en die definisie van produksie- en operasionele bestuurstegnieke skep probleme, maar navorsing dui daarop dat spesifieke doelwitte onafhanklik is. Meer navorsing is nodig om hierdie resultaat te bevestig. Sommige tegnieke is met spesifieke doelwitte verbind en navorsing hiernor behoort uitgebrei te word.
\end{abstract}

\section{Introduction}

In this article conceptual links between the goals of manufacturing strategy and P.O.M. techniques are outlined. Then links are empirically established using a pilot study.

Three concepts which form the title of the article are discussed with the object of establishing research hypotheses.

\section{Goals of manufacturing strategy}

A firm's goals can vary from the single profit measure of neoclassical economists to open-ended lists. Hill (1985: 40) for example expands goals to include colour range, product range and design leadership. Restaurants would include ambience. Managers conceive strategies to pursue specific goals within firms to obtain advantage over their competitors.' However, competitors make moves in a way that ensures that little, if any, advantage may be sustained (Ghemawat, 1986). To generate advantage, all functions of business including manufacturing, need to be investigated and since the early 1970 s there has been a growing awareness of the advantages of managing manufacturing in individual business units to pursue the goals set (Grant, 1991). The purpose of an effective manufacturing strategy is to pursue goals as part of a congruent business strategy. Manufacturing strategy restricts directors and managers in their strategies by the ability of manufacturing to deliver.

From a sample Gray (1984) found that most companies remain committed to strategic planning in business. There is ample literature on the process of strategy but the link between conceived and delivered strategy is not well researched. While there is agrecment between scholars on the need for a coherent strategy for manufacturing, there is little empirical research. One study found a link between strategy and performance. Lindman \& Callarman (1990) found a positive link between consensus on strategy and performance of manufacturing. In betwcen consensus on strategy and performance, implementation exists. It seems that, for manufacturing firms at least, 'the real benefits of manufacturing strategy come from implementing the manufacturing strategy' (Marucheck, et al., 1990: 496). However, Gray (1984) reports that most people are either disappointed or frustrated with strategic planning in business. The disappointment or frustration stems from difficulties in implementation. He gives six components most likely to improve implementation. These are:

1. Prepare line managers.

2. Define business units correctly.

3. Formulate business goals clearly.

4. Plan an adequate action information base.

5. Handle reviews of business unit plans well.

6. Link strategic planning with control systems.

In this article aspects of improving implementation are considered. There are specific management principles which emphasize clear goal sctting.

Older books do not emphasize that goals must be able to be implemented and pursued. The elaboration of a set of goals is no guarantee that they may be pursued. Consider the popular productivity goal. Skinner (1986: 55) points out that there is a productivity paradox. He says "The harder ... companies pursue productivity the more elusive it becomes'. He attributes this to the way managers define productivity and the tools they use to achieve it. Alternatively pursuing productivity may be difficult as perceptions change as to meaning. When middle management communicates upwards, productivity may mean 'profit'. When middle management communicates downwards to workers, productivity may be an excuse for not taking personal responsibility. For example 'I cannot allow you time off because productivity is so low' may mean that the middle manager does not take 
responsibility for saying 'no'. He blames 'productivity'. Low productivity means 'no' to the workers. Productivity means neither 'profit' nor 'no'. (For an understanding of productivity see Snaddon, 1990: 240-241.) Goals may be elusive.

There is a growing literature on the goals which manufacturing systems can deliver as a basis for competition (McLaughlin, et al., 1990: 524). Slack's set of goals is chosen for clarity and as a sufficient range for a first test. Slack (1991) distinguishes between

quality: doing things right (i.e. correctly and well); cost: doing things cheaply;

responsiveness: doing things fast;

dependability: doing things on time; and

flexibility-willing to change. ${ }^{2}$

The goals of responsiveness and dependability are jointly called time.

Even if Slack's set of goals may be pursued there is a problem whether goals are interdependent. If goals are interdependent they cannot be independently pursued. There is evidence that some goals may not be independent. The maxim that 'time is money' may imply that more time leads to less cost. Another example is interdependence of the goals of cost and quality. In competitive situations, price and cost are related at the margin (Samuelson, 1967: 442). As price and quality have been shown to be related (Gabor \& Granger, 1966) there may be an association between cost and quality through the pricing mechanism. Formulating business goals clearly helps implementation. Goals need to be distinguished between independent and interdependent goals.

A question to be researched is which of Slack's goals are independent?

\section{P.O.M. techniques}

It has been suggested that there are more useful as well as less useful techniques. Some suggest that techniques for introducing quality programmes have been more useful than techniques for reducing lead times (Klein, 1990: 1) Such statements are ambiguous as the usefulness of techniques may be only judged in terms of the goals being pursued. The statement can be accepted if striving for quality is the same as pursuing responsiveness. In cases where goals are not the same, this is not true.

Production and operation management (P.O.M.) techniques constitute a method of implementing and monitoring strategies striving after goals. Goals link with P.O.M. techniques. All P.O.M. techniques should, ultimately, help to strive after goals. There should therefore be a link between techniques used and goals pursued. Techniques may be used for more than one goal. Alternatively goals may associate, through techniques, with one another. If goals cannot be distinguished in terms of the techniques, then goals may be interdependent.

Comments have been made on linking appropriate techniques to specific goals. For time-based competition Azzone et al. (1990: 440) suggest total quality control, JIT, and lay out by product. For pursuing quality Leonard \& Sasser (1982: 167) point out the variety of ways that managers can use. Techniques used for pursuing goals may change. ${ }^{3}$
To implement strategy, techniques that support strategy must be found and used to help communicate and monitor work. Important ways in which goals are communicated, are the techniques used. Managers communicate their competitive strategy through the techniques they use. The use of appropriate techniques conveys positive information. Installing inappropriate techniques which conflict with management directives constitute: 'actions which speak louder than words'. It is not only the technique selected but the perception about the association between the technique and goal which determine the effectiveness of pursuing the goal.

\section{Perceptions}

Wheelwright explains that there is a difference between the American and Japanese perceptions about goals. He uses the word 'priorities' for 'goals' and explains the difference as follows:

'American managers generally view manufacturing operations as necessitating trade-offs between competing sets of priorities as cost and quality or flexibility and dependability. To their way of thinking, reducing costs and improving quality are desirable goals that happen to require opposing courses of action. Because both are valuable and because the achievement of one contradicts directly with the achievement of the other, trade-offs are unavoidable'.

'For the Japanese manager, then, the issue is not to force an unnecessary choice between cost and quality but to identify those approaches to quality improvement (as a means) that will help reduce overall costs (as an end)' (1981: 70-71).

While crass stereotyping is debatable, the difference in perceptions indicate different relationships of goals. American managers are portrayed as regarding goals to a large degree as substitutes for one another. Japanese managers are portrayed as regarding goals to a large degree as complementing each other.

Some may argue that perceptions do not alter techniques. They argue that techniques are neutral and people make techniques more or less applicable. (For discussion on the DCF technique see Hayes \& Garvin, 1982). This is an artificial demarcation and is rejected. It is not how techniques may be used to pursue goals that is important. It is how people perceive that techniques may be used to pursue goals that is important.

In implementing strategy it is important to link strategic planning (i.e. goals pursued) with techniques that are perceived to lead to the goals. These techniques include, amongst others, P.O.M. techniques. The second research question is: Which P.O.M. techniques are recommended for these independent goals?

This is in line with linking strategic planning to control systems. It goes beyond the process of strategic planning to choosing techniques for specific steps of the strategic planning process (Webster, et al., 1990).

\section{Research hypotheses and benefits}

Research is initiated into people's perceptions of which P.O.M. techniques associate with specific goals and which goals are independent. 
To sum up there are two major questions to be answered, namely:

1. Which goals are independent?

2. Which P.O.M. techniques are recommended for these independent goals?

There are benefits to be derived from answering the questions, at least for managers and academics. Managers pursue their strategy by forming the strategy, then communicating the important elements thereof where it is required. They do this by, amongst others, installing and championing P.O.M. techniques. To do this there are at least two requirements:

1. Managers must be aware of the P.O.M. techniques.

2. People must perceive that the techniques are useful in communicating the required strategy.

The answers to the questions or research hypotheses go some way to implementing and controlling manufacturing strategy. These answers provide necessary, but not sufficient, conditions for implementing strategy. If goals are independent, managers may control and manipulate goals with some precision thereby gaining advantage. This rifle approach contrasts with a shotgun approach if goals are interdependent. If goals are interdependent then managers may consider delivering a package of goals in a combined, and partly uncontrolled form. Once independent goals are established, an optimum mix of goals may be analyzed. (For the example of optimizing the marketing mix, see Kotler, 1979: 53-63.)

A secondary use of the answers to the research hypotheses is for improved teaching. The correct set of techniques for a specific goal allows teachers to eliminate superfluous information. Research possibilities include management skill measurement over time and in differing industries, nationally and internationally. (This research is important for distance learning programmes.) Another research possibility is to analyze communicated and stated strategy. Communicated strategy is that strategy that is implied by the techniques used and may be compared to management's stated strategy.

\section{Test of hypotheses}

The textbook of Wild (1989) is chosen as a standard source of techniques. It is sufficiently comprehensive and current for an initial test. Standardizing the book is arbitrary, as are standardizing goals. Wild's book, ' ... introduces some theories, ideas and concepts. It deals also with principles, procedures and techniques' (Wild, 1989: vii).

In using this textbook, techniques are distinguished from principles, procedures, concepts, ideas and theories. The Oxford English Dictionary is used to define all these terms. A technique is a 'mechanical skill or art'. A principle is a 'fundamental truth as a basis of reasoning' and a procedure is a 'mode of conducting business (especially in parliament) or legal action'. A technique contrasts with a concept as an 'idea of a class of objects, a general notion', an idea as 'archetype, pattern, ... way of thinking' and a theory as a 'supposition explaining something, especially one based on principles independent of the phenomena'. This research is aimed at things people do rather than things people think. This excludes principles, concepts, ideas and theories.
Another consideration is the scope of a technique. Should a technique be considered to be general, specific or something in between? For example, layout may be identified as a technique. The basic types of layout, such as layout by process, may be a set of techniques. Finally programmes assisting in designing a specific layout (e.g. cross and relationship charts or ALDEP) may each be regarded as a technique.

Four post graduate research assistants individually de. cided what constituted a technique, and only techniques of the same scope are combined during analysis. They independently found and scored the usefulness of techniques from Wild's book using Slack's goals.' The researchers placed techniques in categories designated as follows: 1 means 'use not recormmended'; 2 means 'impartial'; 3 means 'use recommended'; and 4 means 'use strongly recommended'. Researchers identified techniques subjectively, aiming for too many, rather than too few, techniques.

\section{Analysis}

The analysis is done in three parts. In the first part, general observations are made concerning the number of techniques analyzed by each researcher and the overall scoring of goals. In the second part of the analysis, commonly agreed techniques are mentioned and differences between researchers' findings noted. In the final part of the analysis goals are associated with each other and techniques are suggested for independent goals. The data collected is in categories in ordinal form and so the non-parametric chi-squared test $\left(x^{2}\right)$ is used to find significant results. The level of significance is set at $5 \%$ ?.

\section{General observations}

The researchers reported a total of 189 P.O.M. techniques. The number of techniques analyzed by each researcher is given in Table 1. Each technique is scored for the five goals: quality, cost, response, dependability and flexibility. The results are given in Table 2.

If each score has an equal chance of occurring then each score is expected to have 236 observations ( $189 \times 5 / 4)$. The chi-square test shows significant variations in scores $\left(x^{2}\right.$ obs., 3 d.f. $=127$ ). There are too few observations scored where the use is not, or strongly, recommended. There are too many observations scored where the use is recommended.

\begin{tabular}{lc}
$\begin{array}{l}\text { Table } 1 \\
\text { Number of } \\
\text { techniques } \\
\text { each researcher } \\
\text { found by }\end{array}$ \\
\hline $\begin{array}{c}\text { Number of } \\
\text { Researcher }\end{array}$ \\
\hline techniques found \\
B & 68 \\
C & 40 \\
D & 65 \\
\hline Total & 16 \\
\hline
\end{tabular}


Table 2 Scores frequency for goals

\begin{tabular}{lcccccc}
\hline $\begin{array}{l}\text { Goal } \\
\text { score }\end{array}$ & Quality & Cost & Response & $\begin{array}{c}\text { Depend- } \\
\text { ibility }\end{array}$ & $\begin{array}{c}\text { Flex- } \\
\text { sbility }\end{array}$ & $\begin{array}{l}\text { Total } \\
\text { freq. }\end{array}$ \\
\hline $\begin{array}{l}\text { (not recom- } \\
\text { mended) }\end{array}$ & 54 & 21 & 23 & 22 & 62 & 182 \\
$\begin{array}{l}\text { (impartial) } \\
3 \text { (recom- }\end{array}$ & 51 & 28 & 45 & 34 & 52 & 210 \\
$\begin{array}{l}\text { mended) } \\
4 \text { (strongly } \\
\text { recommended) }\end{array}$ & 50 & 94 & 89 & 95 & 56 & 384 \\
\hline \begin{tabular}{l} 
Total freq. \\
\hline
\end{tabular} & 189 & 189 & 189 & 189 & 189 & 945 \\
\hline
\end{tabular}

This implies that researchers show a preference for recommending techniques (see Table 2).

The distribution of scores of quality and flexibility are similar $\left(\chi_{\text {obs., }}^{2} 3\right.$ d.f. $\left.=3.0\right)$. Researchers do not recommend use of $31 \%$ of techniques, recommend use of $28 \%$ of techniques, and strongly recommend use of a further $14 \%$ of techniques. Researchers are impartial to the use or non-use of the remaining $27 \%$ of techniques. The scoring of cost, response and dependability are $\operatorname{similar}\left(\chi_{\text {ots. }}^{2} 6\right.$ d.f. $\left.=7\right)$. Researchers do not recommend use of $12 \%$ of techniques, recommend use of $49 \%$ of techniques, and strongly recommend use of a further $20 \%$ of techniques. Researchers are impartial to the use or non-use of the remaining $19 \%$ of techniques. There are significant differences between scoring the goals of quality and flexibility on the one hand and cost, response and dependability on the other. $\mathrm{Re}$ searchers are more critical of recommending techniques for quality and flexibility than other goals.

\section{Consensus between researchers}

When grouping techniques, strict conformity is required.

Table 3 Agreed techniques

\begin{tabular}{|c|c|c|}
\hline Technique & Chapter in Wild & Researchers \\
\hline \multicolumn{3}{|c|}{ Agreement by all researchers } \\
\hline Automated storage \& retrieval & 6 & $\mathrm{~A} / \mathrm{B} / \mathrm{C} / \mathrm{D}$ \\
\hline MRP & 11 & $\mathrm{~A} / \mathrm{B} / \mathrm{C} / \mathrm{D}$ \\
\hline OPT & 12 & $\mathrm{~A} / \mathrm{B} / \mathrm{C} / \mathrm{D}$ \\
\hline \multicolumn{3}{|c|}{ Agreement by three researchers } \\
\hline Standardization & 2 & $\mathbf{A} / \mathbf{B} / \mathbf{C}$ \\
\hline Time study & 8 & $\mathrm{~A} / \mathrm{B} / \mathrm{D}$ \\
\hline Activity sampling & 8 & $\mathrm{~A} / \mathrm{B} / \mathrm{C}$ \\
\hline JIT & 12 & $\mathrm{~A} / \mathrm{B} / \mathrm{C}$ \\
\hline Reverse scheduling & 12 & $\mathrm{~A} / \mathrm{B} / \mathrm{C}$ \\
\hline Forward scheduling & 12 & $\mathrm{~A} / \mathrm{B} / \mathrm{C}$ \\
\hline Sequencing & 12 & $\mathrm{~A} / \mathrm{B} / \mathrm{C}$ \\
\hline Desparching & 12 & $\mathrm{~A} / \mathrm{B} / \mathrm{C}$ \\
\hline Assignment & 12 & $\mathrm{~A} / \mathrm{B} / \mathrm{C}$ \\
\hline Physical distribution management & 16 & $\mathrm{~A} / \mathrm{B} / \mathrm{C}$ \\
\hline Kanban & 18 & $\mathrm{~A} / \mathrm{C} / \mathrm{D}$ \\
\hline Linear programming & App & $\mathrm{A} / \mathrm{B} / \mathrm{C}$ \\
\hline
\end{tabular}

Researchers must agree that the techniques are of the same scope. For example layout by process is not combined with cross and relationship charts.

All researchers agree on three techniques and three agree on twelve techniques. Given in Table 3 are techniques agreed upon by all and three researchers. Two researchers agree on thirty techniques and the remaining techniques listed are unique. Most of the techniques agreed upon are from chapter 12 of Wild's textbook on activity scheduling.

If there is consensus between researchers then techniques and goals will be equally scored. Scores for the same techniques are tested for each pair of researchers. All goals are included for the tests. One researcher (D) provides too few scores for testing. The scores of the research pairs $A$ and $C\left(\chi_{\text {obs., }}^{2} 4\right.$ d.f. $\left.=4.8\right)$ on the one hand, and $B$ and $C$ $\left(\chi_{\text {obs. }}^{2} 1\right.$ d.f. $\left.=1.7\right)$ on the other, are not significantly associated. A's and B's scores are significantly associated $\left(\chi_{\text {obs. }}^{2} 3\right.$ d.f. $\left.=29\right)$. A's and B's scores demonstrate consensus. Table 7 contains the frequency of scores for agreed techniques of these researchers.

\section{Goal independence}

The independence of goals may be tested at two levels. Goals' scores are associated with each other for all researchers combined, then individually. The results for all researchers are given in Table 8. Significant combined associations are summarized in Table 4 . In this table goals are listed in both the columns and the rows. Where there is a significant association an asterisk is placed in the cell between the relevant row and column. Table 4 is to be read as follows. Look along the 'Quality' row. In the 'Cost' column there is an asterisk and so there is a significant association between cost and quality for all researchers' information. In the 'Response' column there is a dash and so no significant association between response and quality was found for all researchers, information. A triangular section of Table 4 is blank. Either information in this section replicates that in the upper section or, where the row and column have the same goals, perfect association occurs.

For all researchers there are significant associations between cost and quality, response and dependability, and flexibility and all goals excepting dependability.

Table 4 Significant combined association between goals

\begin{tabular}{|c|c|c|c|c|}
\hline All researchers & & & & \\
\hline Coal & Cost & Response & $\begin{array}{l}\text { Depend- } \\
\text { ability }\end{array}$ & $\begin{array}{l}\text { Flex- } \\
\text { ibility }\end{array}$ \\
\hline Quality & $*$ & - & - & * \\
\hline Cost & & - & - & * \\
\hline Response & & & $*$ & $\bullet$ \\
\hline Dependability & & & & - \\
\hline \multicolumn{5}{|l|}{ Notes } \\
\hline $\begin{array}{l}\text { n.t. }=\text { no test: } f_{\text {}} \\
\text { sig. at } 5 \% \text { le }\end{array}$ & & & & \\
\hline
\end{tabular}


Table 5 Significant individual association between goals

Individual researchers

\begin{tabular}{lcccc}
\hline Goal & Cost & Response & $\begin{array}{c}\text { Depend- } \\
\text { ability }\end{array}$ & $\begin{array}{c}\text { Flex- } \\
\text { ibility }\end{array}$ \\
\hline Quality & - & $*$ & - & - \\
Cost & & - & - & $* *$ \\
Response & & & $*$ & - \\
Dependability & & & & - \\
\hline
\end{tabular}

Notes: $n . t .=$ no test; $f_{e}<5 ; *$ sig. at $5 \%$ level

There are forty possible associations between goals for individual researchers' findings. Sixteen tests cannot be made because there are too few expected observations. Results of the remaining tests are reported in Tables 9-11. Of the remaining 24 , four are significant. Significant associations are given in Table 5 for individual researchers. The significant associations are: quality and response for researcher $\mathrm{B}$, cost and flexibility for $\mathrm{A}$ and $\mathrm{C}$, and response and dependability for $\mathrm{A}$.

\section{Specific techniques for P.O.M. goals}

Contained in Table 6 are the average scores recorded by researchers for commonly agreed techniques given in Table 3 .

Table 6 Average scores - goals and commonly agreed techniques

\begin{tabular}{|c|c|c|c|c|c|}
\hline Goal & Quality & Cost & $\mathrm{Ti}$ & me & Time \\
\hline $\begin{array}{l}\text { Commonly agreed } \\
\text { techniques }\end{array}$ & $\begin{array}{l}\text { Average } \\
\text { score }\end{array}$ & $\begin{array}{l}\text { Average } \\
\text { score }\end{array}$ & Res.' & Dep. $^{2}$ & $\begin{array}{c}\text { Average } \\
\text { score }\end{array}$ \\
\hline Standardization & 3.0 & 3.0 & 3.3 & 3.3 & 3.3 \\
\hline \multicolumn{6}{|l|}{ Automated storage \& } \\
\hline retrieval & 2.3 & 2.8 & 3.5 & 3.0 & 3.3 \\
\hline Time study & 1.7 & 3.0 & 3.0 & 3.3 & 3.2 \\
\hline Activity sampling & 2.0 & 2.0 & 2.3 & 3.0 & 2.7 \\
\hline MRP & 2.4 & 3.4 & 3.4 & 3.3 & 3.3 \\
\hline Reverse scheduling & 2.3 & 2.0 & 1.7 & 3.2 & $2.5^{*}$ \\
\hline Forward scheduling & 2.0 & 2.7 & 1.7 & 3.3 & $2.5^{*}$ \\
\hline Sequencing & 2.3 & 3.0 & 3.7 & 2.0 & $2.8 *$ \\
\hline Dispatching & 2.3 & 2.0 & 3.3 & 2.7 & 3.0 \\
\hline Assignment & 2.3 & 2.3 & 3.3 & 2.7 & 3.0 \\
\hline OPT & 2.5 & 3.5 & 3.5 & 3.3 & 3.4 \\
\hline JIT & 3.0 & 3.7 & 3.3 & 2.7 & 3.0 \\
\hline Kanban & 2.7 & 2.7 & 3.3 & 3.0 & 3.1 \\
\hline \multicolumn{6}{|l|}{ Physical distribution } \\
\hline management & 1.7 & 3.0 & 3.0 & 3.3 & 3.1 \\
\hline Linear programming & 2.0 & 4.0 & 2.7 & 2.7 & 2.7 \\
\hline
\end{tabular}

1. Res. stands for response

2. Dep. stands for dependability

* Marks where the averages of response and dependability vary by more than 1.

Scoring key: 1 = use not recommended, 2 = imparial, 3 = recommended, and 4 = strongly recommended.
Average scores are shown for quality, cost and two time goals, response and dependability as a guide. The average scores indicate that, for example, when quality is pursued, standardization and J.I.T. are recommended.

\section{Discussion}

The research is biased by the choice of book and researchers.

When discussing results about perceived interdependence of goals, care must be exercised. If techniques are equally useful for different goals, then there are two explanations. Goals may be interdependent. There is an altemative explanation for the manager's perceptions. Techniques may be generally applicable for many goals, but managers tailor a technique to the goal desired. Consider standardization in Table 6. It is recommended to the same degree for quality, cost and response and dependability. Wild (1989: 80) explains standardization as embracing the control of unspecified variety and this could apply to all the goals in Table 6. The astute manager can adapt standardization as a technique to pursue quality, cost or time goals.

Full analysis was restricted because of the paucity of observations and because researchers preferred to recommend techniques especially for cost, response and dependability.

Common techniques found by researchers are from a limited part of Wild's book. (About one half of the common techniques deal with activity scheduling.) Two or more researchers agree on the same technique for $55 \%$ of the observations. There is not strong agreement between researchers regarding the use of techniques. Of the three researchers who supplied sufficient information two displayed some degree of consensus. Conclusions are derived for the hypotheses from individual and combined tests (see Tables 4 and $5)$.

Response and dependability are associated in both the combined and individual tests. A more fruitful arrangement may be to combine response and dependability into a time goal. This combination is reasonable in terms of associations but there are techniques which require more research. Examples, from Table 6 , are reverse and forward scheduling and sequencing. Forward and reverse scheduling is advocated more strongly for dependability than response. Sequencing is advocated more strongly for response than dependability. However, until research is undertaken to show the contrary, response and dependability are considered to combine into a time goal.

Flexibility associates with all goals except dependability. As response and dependability associate, flexibility should combine with other goals e.g. use cost in an absolute and flexible manner. Flexibility may not be an independent goal.

Cost associates with quality in combined, but not in individual associations. The combined result appears to validate the theoretical stance given in the introduction for associating cost and quality. Care must be taken when deriving conclusions from combined researchers. If one researcher scores 1 for all techniques and a second researcher scores 4 for all techniques then this would give a biased result which would appear to be perfectly combined. In other words combined results can display good associations if individuals score in a biased manner. A conservative stance 
is taken that more evidence is needed before this association is accepted.

There is no significant association between time and cost. This is an interesting rejection of the maxim that time is money especially when the critical path method integrates time and cost.

Commonly agreed techniques for specific goals may be read directly off Table 6 . Techniques such as standardization are useful for most goals but other techniques give divergent results, e.g. time study is recommended for dependability but not for quality.

\section{Conclusions and further research}

A method to research the association between goals and P.O.M. techniques is explained. It may be extended to other goals and techniques. Within the limitations discussed the following results appear from this research:

1. Flexibility appears to associate with all the other variables. Flexibility may be a derived competitive variable. Flexibility may not be pursued as a goal but in conjunction with other goals e.g. cost flexibility.

2. Response and dependability may be combined into a time goal.

3. Quality, cost and time are not strongly associated. They should be treated separately in setting a strategy. Managers can choose either quality, cost, or time or a combination of these goals to pursue and gain differential advantages from their competitors.

4. Specific P.O.M. techniques for goals are identified. P.O.M. techniques may be found for goals in Table 6. Managers, teachers and researchers may use the results to lower the costs of search.

Further research is required. This may include validating and improving the research undertaken here. In such research there may be merit in selecting some techniques for analysis. Other tests should be conducted to see if books and researchers change the perceptions of important P.O.M. techniques and goals. Results should be validated by people with experience of a wide variety of techniques.

\section{Notes}

1. In this article specific goals are italicized in the text.

2. The goals are simple. Even so they are subject to misunderstanding. For example economists and accountants view cost in different ways (see Solomons' (1970) set of readings, especially those by Coase, and Baxter \& Oxenfeldt).

3. In pursuing cost some people feel that improvements in techniques are required (Eiler, et al., 1982).

4. Definitions are not given for all the priorities (goals). Wheelwright has explained flexibility as an 'ability to respond to short term fluctuations in the marketplace' (1981: 73).

5. I thank the research assistants: Hammann J., Lorenz A., Ngobeni J.E. and Partridge A.

6. Prior to reading the book, researchers were acquainted with between a third and a half of the techniques that they listed.

7. Critical $\chi^{2}$ values at $5 \%$ level are 1 d.f. $=3.841 ; 2$ d.f. $=$ $5.991 ; 3$ d.f. $=7.815 ; 4$ d.f. $=9.488 ; 6$ d.f. $=12.592$

\section{Autoblographical note}

Dr Roy Snaddon is a professional and certificated engineer in South Africa and a chartered engineer in the United Kingdom. He is presently a senior lecturer at the University of the Witwaterstand. Before joining the University he worked as in engineer, a financial manager and a managing director. 'For any good in this work to God be the glory.'

\section{Keywords}

Strategy, techniques, strategic management.

\section{References}

Azzone, G. Masella, C. \& Bertele, U. 1990. 'Performance measurement for time based competition'. In: Voss, C.A. (ed.). Manufacturing strategy - theory and practice. Proceed. ings of the 5th International Conference of the Operations Management Association U.K., pp.428-441. Held at the University of Warwick: MCB University Press, 26th-27th June 1990. 1014p.

Eiler, R.G., Goletz, W.K. \& Keegan, D.P. 1982. 'Is your cost accounting up to date?', Harvard Business Review, Vol. 60, No. 4: $133-139$.

Gabor, A. \& Granger, G.W.J. 1966. 'Price as an indicator of quality: report of an enquiry', Economica, Vol. 33: 43-70.

Ghemawat, P. 1986. 'Sustainable advantage', Harvard Business Review, Vol. 64, No. 5: 55-58.

Grant, R.M. 1991. 'The resource based theory of competitive advantage: implication for strategy formulation', California Management Review, Spring, Vol. 33, No. 3: 114-135.

Gray, D.H. 1986. 'Uses and misuses of strategic planning', Harvard Business Review, Vol. 64, No. 1: 89-96.

Hayes, R.H. \& Garvin, D.A. 1982. 'Managing as if tomorrow mattered', Harvard Business Review, Vol. 60, No. 3: 71-79, communications published Harvard Business Review, Vol. 60 , No. 5: 185-201.

Hill, T. 1985. Manufacturing Strategy. Basingstoke: Macmillan. $230 \mathrm{p}$.

Klein, J.A. 1990. Instructor's manual to accompany revitalizing manufacturing-lext and cases. Boston: Irwin. 385p.

Kotler, P. 1979. Marketing decision making - a model building approach. London: Holt-Saunders Intemational Editions. $720 \mathrm{p}$.

Leonard, F.S. \& Sasser, W.E. 1982. 'The incline of quality', Harvard Business Review, Vol. 60, No. 5: 163-171.

Lindman, F. \& Callarman, T. 1990. 'The influence of SBUmanufacturing strategic consensus on operational performance: an empirical investigation'. In: Voss, C.A. (ed.). Manufacturing strategy theory and practice. Proceedings of the 5th International Conference of the Operations Management Association U.K., 388-401. Held at the University of Warwick, 26th-27th June 1990: MCB University Press. 1014p.

Marucheck, A., Pannesi, R. \& Anderson, C. 1990. 'An exploratory study of the manufacturing strategy process in practice'. In: Voss, C.A. (ed.). Manufacturing strategy theory and practice. Proceedings of the 5th International Conference of the Operations Management Association U.K., 450-501. Held at the University of Warwick, 26th-27th June 1990: MCB University Press. 1014p.

McLaughlin, C.P., Pannesi, R. \& Narindar, K. 1990. 'The different operations strategy planning process for service operations.' In: Voss, C.A. (ed.). Manufacturing strategy theory and practice. Proceedings of the 5 th International Conference of the Operations Management Association U.K., 502-529. Held at the University of Warwick, 26th-27th June 1990: MCB University Press. 1014p.

Samuelson, P.A. 1967. Economics. 7th International student ed., Tokyo: Mc Graw-Hill Book Co. 821 p. 
Skinner. W. 1969. 'Manufacturing - missing link in corporate strategy', Harvard Business Review, Vol. 57, No. 3: 136-145.

Skinner, W. 1986. 'The productivity paradox', Harvard Business Review, Vol. 64, No. 4: 55-57.

Slack. N.D.C. 1991. The manufacturing advantage. London: Mercury.

Snaddon, D.R. 1990. 'Productivity within sections of firms - 1 . The design of a productivity measure for a section of a firm', Technovation, Vol. 10, No. 4: 235-251.

Solomons, D. 1970. Studies in cost analysis. 2nd ed., London: Sweet and Maxwell. $561 \mathrm{p}$.

Webster, J.L., Reif, W.E. \& Bracker, J.S. 1990. 'The manager's guide to strategic planning tools and techniques', Engineering Management Review, Dec., Vol. 18, No. 4: 108-118.

Wheelwright, S.C. 1981. 'Japan where oper ations really are strategic', Harvard Business Review, Vol. 59, No. 4: 67-74.

Wild, R. 1989. Production and operations management. 4th ed., London: Cassell. 792p.

\section{Appendlx 1}

Table 7 Association between researchers $B$ and $A$

\begin{tabular}{lrrrrr}
\hline B/A & 1 & 2 & \multicolumn{1}{c}{3} & 4 & Total \\
\hline 1 and 2 & 30.5 & 7 & 9.5 & 0 & 47 \\
3 and 4 & 10 & 8 & 20 & 15 & 53 \\
Toul & 40.5 & 15 & 29.5 & 15 & 100
\end{tabular}

The reason for half observations is that there are some cases where a researcher classified a 'technique' twice, as it appears iwice in the textbook. $\chi^{2}$ obe. 3 degrees of freedum is 28.8737 .

\section{Appendix 2}

Table 8 Association between goals - all

Researcher: all

No. of obs.: 189

\begin{tabular}{|c|c|c|c|c|c|}
\hline Gool & & Cost & Response & $\begin{array}{l}\text { Depend- } \\
\text { ability }\end{array}$ & $\begin{array}{l}\text { Flex- } \\
\text { ibility }\end{array}$ \\
\hline \multirow[t]{2}{*}{ Quality } & $x^{2}$ & $54.8205^{*}$ & 10.5923 & 5.1128 & $43.4040^{*}$ \\
\hline & d.f. & 6 & 6 & 6 & 6 \\
\hline \multirow[t]{2}{*}{$\operatorname{Cost}$} & $x^{2}$ & & 8.4680 & 2.4414 & $19.5642^{*}$ \\
\hline & d.f. & & 4 & 4 & 6 \\
\hline \multirow[t]{2}{*}{ Response } & $x^{2}$ & & & $19.1736^{*}$ & $21.4842 *$ \\
\hline & d.f & & & 4 & 6 \\
\hline \multirow[t]{2}{*}{ Dependability } & $x^{2}$ & & & & 11.7941 \\
\hline & d.f. & & & & 6 \\
\hline
\end{tabular}

Nore: $n . L=$ no test; $f_{*}<5 ;=$ sig. at $5 \%$ level

The same analysis is provided for the researchers A, B and $\mathrm{C}$ in Tables 9-11.
Table 9 Association between goals A

Researcher: A

No. of obs.: 68

\begin{tabular}{|c|c|c|c|c|c|}
\hline Goal & & Cost & Response & $\begin{array}{l}\text { Depend- } \\
\text { ability }\end{array}$ & $\begin{array}{l}\text { Flex- } \\
\text { ibility }\end{array}$ \\
\hline \multirow[t]{2}{*}{ Quality } & $x^{2}$ & 1.4932 & 2.078 & 0.0023 & 1.3418 \\
\hline & d.f. & 1 & 2 & 1 & 1 \\
\hline \multirow[t]{2}{*}{$\operatorname{Cost}$} & $x^{2}$ & & 2.9107 & 5.3377 & $5.3328^{*}$ \\
\hline & d.f. & & 2 & 2 & 1 \\
\hline \multirow[t]{2}{*}{ Response } & $x^{2}$ & & & $24.2123^{*}$ & 0.1271 \\
\hline & d.f & & & 2 & 1 \\
\hline \multirow[t]{2}{*}{ Dependability } & $x^{2}$ & & & & 0.0975 \\
\hline & d.f. & & & & 1 \\
\hline
\end{tabular}

Noce: $n . t=$ no test; $f_{a}<5 ; *=$ sig. at $5 \%$ level

Table 10 Association between goals B

Researcher: B

No. of obs.: 40

\begin{tabular}{llllll}
\hline Goal & & Cost & Response & $\begin{array}{l}\text { Depend- } \\
\text { ability }\end{array}$ & $\begin{array}{l}\text { Fiex- } \\
\text { ibility }\end{array}$ \\
\hline Quality & $\chi^{2}$ & 1.3636 & $9.6970 *$ & 0.6838 & 0.3039 \\
& d.f. & 1 & 1 & 1 & 1 \\
Cost & $\chi^{2}$ & & 1.3199 & 0.6089 & 1.5759 \\
& d.f. & & 1 & 1 & 1 \\
Response & $\chi^{2}$ & & & 0.61544 & 1.7094 \\
& d.f & & & 1 & 1 \\
Dependability & $\chi^{2}$ & & & & n.t \\
& d.f. & & & & \\
& & & & &
\end{tabular}

Nate: $n . L_{\text {. }}=$ no testi $f_{\mathrm{e}}<5 ; *=$ sig. at $5 \%$ level

Table 11 Association between goals C

Researcher: C

No. of obs.: 65

\begin{tabular}{llllll}
\hline Goal & & Cost & Response & $\begin{array}{l}\text { Depend- } \\
\text { ebility }\end{array}$ & $\begin{array}{l}\text { Flex- } \\
\text { ibility }\end{array}$ \\
\hline Quality & $\chi^{2}$ & 7.6987 & n.t. & n.t. & 0.4307 \\
& d.f. & 4 & & & 2 \\
Cost & $\chi^{2}$ & & n.t. & 3.0499 & $6.1094 *$ \\
& d.f. & & & 2 & 2 \\
Response & $\chi^{2}$ & & & n.t. & n.t. \\
& d.f & & & & \\
Dependability & $\chi^{2}$ & & & & 1.0943 \\
& d.f. & & & & 1 \\
\hline
\end{tabular}

Note: n.t. $=$ no test; $f_{\mathrm{q}}<5 ; *=$ sig. at $5 \%$ level

The reason for no test is that many frequencies were clustered in the ' 3 ' category. Adding adjacent calegories does not help. 